Dr JASMINA MILANOVIĆ, viši naučni saradnik

Institut za savremenu istoriju

Beograd, Trg Nikole Pašića 11

jasmina.mil17@gmail.com

originalan naučni rad

primljeno: 25. mart 2016.

prihvaćeno: 23. novembar 2016.
UDK 323.1(=163.41)(497.55/.56)"190/191"

070ВАРДАР"190/191"

061.23-055.2(497.11)"190/191"

\title{
BOSNA I HERCEGOVINA U VARDARU - KALENDARU KOLA SRPSKIH SESTARA
}

APSTRAKT: Humanitarno društvo Kolo srpskih sestara osnovano u Beogradu 1903. godine kao svoj glavni cilj isticalo je pomoć srpskom narodu u Osmanskom i Austro-Ugarskom carstvu. Od 1906. godine društvo je počelo da izdaje svoj godišnji kalendar, simbolično nazvan Vardar. Sadržaj lista je bio prilagođen njegovom osnovnom zadatku, kao i književni radovi i ilustracije koje su objavljivane. Od 1908. godine i promene položaja srpskog stanovništva u Staroj Srbiji i Makedoniji, akcenat je stavljen na Bosnu i Hercegovinu. Položaj Srba na ovim teritorijama postala je glavna tema u kalendaru. Mnogobrojni dopisi stizali su redakciji iz Sarajeva, Banja Luke i drugih mesta. Svaka prilika je korišćena za bliži kontakt i razmenu informacija. Tako je Kolo srpskih sestara na sahranu slavne Adeline Irbi u Sarajevu 1911. poslalo svoju upravnu članicu i osnivača Delfu Ivanić. Na put je pošla sa Živojinom Dačićem, sekretarom Narodne odbrane, pa su svoj boravak i posetu Sarajevu i Banja Luci iskoristili i za druge aktivnosti, naravno uvek pod budnim okom austrougarskih vlasti. Redakcija Vardara je održavala i prisne veze sa Nikolom Kašikovićem urednikom Bosanske Vile, kao i sa članicama Dobrotvornih zadruga Srpkinja u Sarajevu i Banja Luci.

KLJUČNE REČI: Bosna i Hercegovina, Kolo srpskih sestara, kalendar Vardar, Narodna odbrana, Nikola Kašiković

\section{Kolo srpskih sestara i glasilo Vardar}

Kolo srpskih sestara je osnovano 1903. godine u Beogradu kao žensko patriotsko i humanitarno društvo. Povod za njegovo osnivanje bila je želja da se pomogne srpskom stanovništvu u Osmanskom carstvu, a naročito onima koji su živeli na teritoriji Stare Srbije i Makedonije. Krajem 19. i početkom 20. veka njihov položaj se pogoršao, a progoni, zatvaranja i ubis- 
tva Srba su bivali sve češći. U to vreme se u Skoplju nalazio Ivan Ivanić, ${ }^{1}$ srpski vicekonzul, koji je u tom gradu upoznao i svoju buduću suprugu Del$\mathrm{fu}^{2}{ }^{2}$ nastavnicu u Višoj ženskoj školi. Društveni angažman vremenom će zauzeti prvo mesto u životu Delfe Ivanić, pa je ona svoju prvu humanitarnu akciju sprovela u Skoplju već 1902. godine kada je uspela da odnese hranu i odeću u zloglasni ženski zatvor Kuršumli-han. Druga velika akcija koju u ovom periodu pominje jeste trud da se 300 srpskih škola u Staroj Srbiji i Makedoniji snabdeju knjigama koje su u Turskoj bile zabranjene, pa su ih konzularni službenici krijumčarili u diplomatskoj pošti. U Skoplju su Ivanići boravili do juna 1903. godine, a po povratku u Beograd Delfa je svoju prijateljicu Nadeždu Petrović detaljno upoznala sa stanjem na jugu. U to vreme u Srbiji, osim Društva Svetog Save, nije postojalo nijedno drugo patriotsko muško društvo, pa Delfa sa ponosom kazuje: „Služi na čast srpskim ženama što su stvorile dve patriotske organizacije svoje i pre Srpske Braće i pre Narodne Odbrane. "3

Kolo srpskih sestara je osnovano u malom krugu prijatelja u kući porodice Petrović u leto 1903. godine. Na prvom sastanku su bili prisutni: Nadežda Petrović i njeni roditelji, Mica Mišković, Julka Janjić, Marija Jelačić Pavlović, Kosara Cvetković, Jelena Lazarević, Delfa i Ivan Ivanić. Na drugom sastanku pridružio im se i Branislav Nušić, koga je Ivanić znao od ranije, iz vremena kada su obojica bila u diplomatskoj službi u Makedoniji. Ime društva su smislili Branislav Nušić i Ivan Ivanić, a zatim su napisali i Pravila, poznatija kao Statut „Kola srpskih sestara“. Prvi, osnivački skup

${ }^{1}$ Ivan Ivanić (1867-1935), diplomata, nacionalni radnik, pisac. Završio je prava u Budimpešti. Učestvovao je u nacionalnom životu Srba u Ugarskoj, bio gonjen, prebegao je u Srbiju ali je proteran u Rumuniju. Posle abdikacije kralja Milana vratio se u Srbiju. Kao konzularni činovnik službovao je u Budimpešti, Prištini, Solunu, Bitolju, Skoplju, Carigradu, a zatim je bio i šef Presbiroa. Tokom Prvog balkanskog rata bio je sekretar za stranu prepisku u štabu III armije, a kasnije činovnik ratnog Presbiroa Vrhovne komande u Skoplju. Postavljen je za načelnika Lješkog sreza, zatim i Dračkog okruga. Po završetku Prvog svetskog rata postaje državni komesar u Vršcu. Bio je urednik mnogih listova i sekretar „Srpskog novinskog društva“. Napisao je: Makedonija i Makedonci, Iz crkvene istorije Srba u Turskoj u 18. i 19. veku, Bunjevci i Šokci, Na Kosovu i druga dela.

2 Delfa Ivanić (1881-1972), humanitarni radnik, novinar, predsednica Kola srpskih sestara, predsednica Ženskog saveza, borac za prava žena. Jedan je od osnivača Kola srpskih sestara, pokretač i urednik kalendara Vardar. Inicijator je stvaranja Četvrte rezervne bolnice u vreme Prvog balkanskog rata, a formirala je i bolnice u Lješu i Draču gde je obolela od tifusa. Po izbijanju Velikog rata u Skoplju radi sa ledi Pedžet na otvaranju bolnice engleske misije. Posle povlačenja iz Srbije, u Nici osniva sa Stankom Lozanić Komitet srpskih žena. Po završetku rata radi na otvaranju Američkog doma za decu bez roditelja u Čačku i Invalidskog doma u Beogradu. Bila je prva Srpkinja koja je dobila medalju „Florans Najtingejl“ 1919. godine. Dobila je Ratnu medalju Crvenog krsta i Orden Svetog Save.

${ }^{3}$ Delfa Иванић, Усйомене, приредила Јасмина Милановић (Београд: Институт за савремену историју, 2012). 
novog društva održan je u sali kod Kolarca 15/28. avgusta 1903. uz učešće preko tri hiljade žena. Skup je govorom otvorila Nadežda Petrović, koja je postala i sekretar društva. Pročitana su pravila, izabrana je uprava, a za prvu predsednicu je izabrana Savka Subotić. Svoj rad novo društvo je zasnivalo na već prihvaćenim i poznatim metodama rada ženskih društava $u$ Srbiji, poput Beogradskog ženskog društva i Društva „Kneginja Ljubica“. ${ }^{4} \mathrm{O}$ ciljevima Kola srpskih sestara članice su pisale u više navrata: „Celokupan rad Kola svodi se u glavnom na tri tačke: Na buđenje narodne svesti u našim neoslobođenim krajevima; na deljenje pomoći onima koji su stradali u borbi za naša narodna prava; i na pribiranje materijalnih sredstava." ${ }^{5}$ Članice društva su odmah pristupile prikupljanju pomoći i već u zimu, krajem 1903. godine, otišle su Nadežda Petrović i Milica Dobri, potpredsednica Kola, u Staru Srbiju i Makedoniju. Obišle su Kozjak planinu i zbegove koji su se tamo sklonili i odnele im pomoć. Stupile su u kontakt i s Lazom Kujundžićem, vojvodom.

Kada se 1905. godine Savka Subotić zahvalila na časti, jer zbog godina i bolesti nije mogla više da vrši dužnost, za novu predsednicu je izabrana Ljubica Luković. ${ }^{6}$ Za potpredsednicu je izabrana Stanislava, supruga Romana Sondermajera, lekara i kasnije načelnika vojnog saniteta. Tokom 1906. godine nova uprava je započela dve važne akcije koje će doprineti njihovom humanitarnom i patriotskom radu. „Kolo srpskih sestara“ je te godine započelo sistematsku obuku svojih članica za bolničarke. Tromesečni kursevi su se održavali u hirurškoj sali dr Vojislava Subotića, sina Savke Subotić. Tokom prvog kursa koji je trajao tri meseca obučeno je 30 članica Kola, koje su potom svake godine išle i na dodatne kurseve. Do početka ratova bilo je samo iz Kola obučeno preko 1.500 bolničarki. Druga velika akcija Kola započela je još 1905. godine, kada je posle nekoliko sastanaka u kući Ivanića odlučeno da se pokrene godišnji kalendar. Ivan Ivanić je predložio da se zove Vardar, pa je već i naslovom novog glasila data osnovna smernica i najavljeni sadržaji. Nekoliko prvih brojeva uredili su Ivan Ivanić

4 Делфа И. Иванић, „Пре двадесет година“, Bapgap, каленgар за 1924, Београд, (1923), 2-32; Љиљана Милојевић-Шуловић и Будимир Павловић, Коло срйских сестиара и Краљии, Марија (Београд: Љ. Милојевић-Шуловић, Б. Павловић, 2000).

${ }^{5}$ Bapgap, каленgap за йросйу їoguнy 1909, година четврта, издање Друштва „Кола српских сестара“, Београд, (1908), 23.

${ }^{6}$ Ljubica Luković (1855-1915), humanitarna radnica. Supruga generala Stevana Lukovića, bila je članica Beogradskog ženskog društva i potpredsednica Društva „Kneginja Ljubica“. Na početku balkanskih ratova radi na formiranju Četvrte rezervne bolnice. Tokom Prvog svetskog rata po dolasku u Niš otvara magacin Kola gde prikuplja hranu, odeću i sanitetski materijal i radi u bolnicama. Januara 1915. odlazi u Valjevo kako bi odnela rublje i pomoć. Požrtvovano negujući ranjenike i sama se zarazila tifusom od koga je preminula u Nišu 11. februara 1915. godine. Posmrtno je odlikovana Ordenom milosrđa „Florans Najtingejl" 1925. godine. 
i Milojko Veselinović. Ovaj kalendar je postao svojevrsna narodna čitanka sa ogromnim tiražima (od 20.000 do 40.000 primeraka). Kalendar je širen kako po Srbiji, tako i po drugim krajevima iako je zvanično bio zabranjen na teritoriji Osmanskog carstva i Habzburške monarhije. Izlazio je jednom godišnje i od 1906. do 1913, a zatim od 1920. do 1940. objavljeno je ukupno 29 brojeva. U uređivanju glasila učestvovale su gotovo sve upravne članice, a posebno Delfa Ivanić, koja je napisala i veći broj članaka.

Svaki broj je počinjao istim uvodim tekstovima: rodoslov vladarskog doma, crkvena uprava, državne svetkovine, praznični dani, kalendar, sa obeleženim mesecima po zvaničnim imenima, ali i uz stare slovenske nazive, a do 1919. dat je i stari i novi kalendar, jer je u Srbiji još uvek bio na snazi stari Julijanski način računanja vremena. Posle kalendara sledila je u početku kratka hronologija pod naslovom „Srpske znamenite godine“. Kao uvod u glavni deo kalendara uvek je štampana pesma Vojislava Ilića „Na Vardaru“, koja je bila i jedna od inspiracija da se i kalendar Kola nazove Vardar.

Kako je Vardar bio pre svega glasilo Kola srpskih sestara, u svakom broju je obavezno štampan Izveštaj o radu društva, a na kraju broja i finansijski izveštaj, kao i izveštaji o radu podružnica društva. Posebnu vrednost ovi izveštaji imaju danas jer su oni gotovo jedini izvor za rad Kola srpskih sestara koje je moralo dva puta da spaljuje svoju arhivu, u Nišu 1914. i u Beogradu 1942. godine. Vardar je brzo stekao mnoge poklonike zahvaljujući i tome što je bio moderno uređena knjiga, sa velikim brojem dobrih tekstova ali i velikim brojem ilustracija, crteža i fotografija. Gotovo sve ilustracije su bile propraćene opširnim tekstovima.

U početku su prilozi u kalendaru bili pretežno književni. Uskoro su mnogi istaknuti intelektualci, književnici, naučnici, kulturni radnici počeli da objavljuju svoje tekstove: književne priloge, naučno-popularne tekstove iz istorije, etnologije, sociologije, ali i politički obojene, patriotske tekstove. U kalendaru su svoje radove objavljivali mnogi književnici poput Petra Kočića, Alekse Šantića, Jovana Dučića i drugih, ali i već ugledni istoričari Stanoje Stanojević, Vladimir Ćorović, teolog Radoslav M. Grujić, diplomata Ivan Ivanić, arhitekta Aleksandar Deroko i drugi. Vremenom u kalendaru počinju da se štampaju i politički obojeni tekstovi i reportaže. To je bilo značajno, ne toliko zbog domaće publike, već više zbog Srba na teritoriji Osmanskog i Habzburškog carstva do kojih je Vardar dolazio raznim kanalima i načinima.

Primarni cilj osnivača i uredništva Vardara bio je dvojak, s jedne strane stanovništvo Kraljevine Srbije je trebalo upoznati sa položajem Srba van granica zemlje, sa njihovim teškim životom pod tuđinskom vlašću. S druge strane, patriotske i nacionalne ideje je trebalo plasirati van granica 
Kraljevine, upoznati i obrazovati tamošnje Srbe sa težnjama matice, uliti im nadu u skoru slobodu i ujedinjenje. Ovi ciljevi su definisani i u tekstu Izveštaja o radu Kola za 1907. godinu rečima: „Negujmo u našoj deci na prvome mestu ljubav spram svega što je srpsko, jer je ona najbolji učitelj. Neka je svako srpsko dete vezano srcem svojim za svoju Otadžbinu: neka skroz poznaje svoj narod; neka se diči njegovim vrlinama a neka ga peku njegove mane. Neka mu je srpska reč najslađa, srpska pesma najmilija, srpsko nebo najvedrije, a srpska beda najbliža; neka usplamti kad vidi Srpsku Zastavu, a Beli Dvoglavni Orao neka mu je druga ikona!“7 Jedan od dobrih primera za širenje ovih ideja jeste i tekst koji je prvo nosio naziv „Karta srpskih i ostalih jugoslovenskih zemalja" autora Svetozara Tomića, kasnije preimenovan u „Srpske zemlje“ koji je objavljivan od 1908. godine.

\section{Vardar o Staroj Srbiji i Makedoniji}

Prvi broj Vardara za 1906. godinu objavljen je prvo u 15.000 primeraka što je za tadašnje srpske prilike bio ogroman tiraž. Kako je, međutim, kalendar za kratko vreme prodat štampano je i drugo izdanje u tiražu od 25.000 primeraka. U ovom broju pored Statuta Kola i informacija o Društvu uglavnom su objavljeni književni prilozi i ilustracije koje su u celini posvećeni Staroj Srbiji i Makedoniji. ${ }^{8}$ Do Prvog svetskog rata najviše priloga u Vardaru bilo je o četničkoj akciji i o starim srpskim spomenicima, manastirima i crkvama u Makedoniji. Štampani su prilozi o neoslobođenim srpskim oblastima i o Crnoj Gori, kao i literarni prilozi patriotskog karaktera. Kako su u periodu od 1905. do 1907. posebno bile zaoštrene borbe i sukobi srpskih četnika sa bugarskim komitskim četama, i u Vardaru je dato posebno mesto ovim događajima. ${ }^{9} \mathrm{U}$ toj borbi srpski četnici su uspeli da u prvoj polovini 1907. potpuno očiste desnu stranu Vardara, posle bitke kod sela Drenove, od bugarskih komitskih četa. Zahvaljujući posredovanju velikih sila, dalji sukob je zaustavljen na neko vreme. Sukobi su prestali tek u leto 1908. izbijanjem mladoturske revolucije. U kalendaru Vardar su često objavljivani tekstovi o junaštvu i herojskim podvizima četničkih vojvoda: Micka Krstića, Jovana Stojkovića - Babunskog, Lazara Kujundžića, Vasilija Trbića. Posebnu pažnju uredništvo lista je posvećivalo poginulim i ubijenim rodoljubima objavljujući redovno njihove fotografije i kratke biografije. U neko-

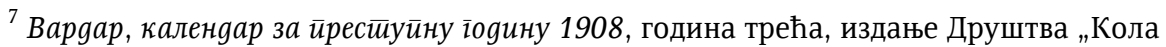
српских сестара“, Београд, (1907), 27.

8 Bapgap, каленgap за pegoвну їoguну 1906, година прва, издање Друштва „Кола српских сестара“, Београд, (1906), тираж првог издања 15.000, тираж другог издања 25.000, (стр. 83+2); формат $24 \times 16 \mathrm{~cm}$.

9 Јован Симијановић, „Календар Вардар о Старој Србији“, Башйина, св. 24, Приштина-Лепосавић, (2008), 191-200. 
liko brojeva na kraju kalendara su davani spiskovi ubijenih Srba u Staroj Srbiji i Makedoniji. Tako je u kalendaru 1907. pored desetak fotografija poginulih i njihovih biografija, objavljen spisak i opis trinaest borbi vođenih 1905. i 1906. godine. U tekstu „Mučka ubistva i nevine žrtve“ kalendar donosi, po oblastima, spisak ubijenih sa kraćim opisom kako su nastradali i imenima preko pedeset žrtava turskog, bugarskog i arnautskog terora. Ovakvih opisa i tekstova ima i u kasnijim brojevima kalendara pod različitim naslovima. Štampani su prilozi o neoslobođenim srpskim oblastima i o Crnoj Gori, kao i literarni prilozi patriotskog karaktera. U međuratnom periodu su objavljivani prilozi iz cele Kraljevine SHS, kasnije Jugoslavije.

Situacija u Staroj Srbiji i Makedoniji, međutim, nije se posle ustavnih reformi 1908. mnogo popravila. Kalendar Vardar pod naslovom „Naša čitulja - naši jadi“ 1910. godine donosi spisak od preko šezdeset ubijenih Srba u prethodne dve godine, spisak spaljenih kuća, škola i crkava. Godine 1912. u tekstu „Crna srpska čitulja - Crni jadi“ objavljen je spisak sa preko devedeset imena ubijenih muškaraca, žena i dece na Kosovu i u Makedoniji.

Novu nadu srpskom stanovništvu ulila je poseta kralja Petra I Carigradu marta 1910. i njegov put od Soluna preko Velesa, Skoplja, Kumanova gde ga je na svim stanicama srpski narod oduševljeno dočekivao i ispraćao. Na tome putu kralja Petra je, od Carigrada do Beograda, zvanično pratio i Ivan Ivanić, na izričit poziv Nikole Pašića i Milovana Milovanovića. Verovatno je Ivanić bio i pisac opširnog teksta o tom putu koji je objavljen u Vardaru za 1911. godinu.

\section{Prilozi u Vardaru o Bosni i Hercegovini}

U početku je kalendar Vardar na teritoriju Osmanskog carstva uglavnom krijumčaren i krišom čitan, dok je na teritoriji Austro-Ugarske mogao da se nađe u knjižarama i kupi. Veću pažnju će uredništvo kalendara početi da posvećuje srpskom narodu u Bosni i Hercegovini već od drugog broja. Odjeci povodom takvih tekstova su bili vrlo povoljni, pa je u jednom od brojeva uprava Kola konstatovala i sledeće: „A u Bosni napamet su ga naučili; jer ono što je u srcu naroda, ne može nikakva cenzura izbrisati, niti kakva vlast ugušiti."

U drugom broju Vardara od ukupno 20 priloga, pored izveštaja o radu društva i pet priloga uz tri ilustracije o Staroj Srbiji i Makedoniji, bilo je i nekoliko književnih priloga o Bosni i Hercegovini. ${ }^{10}$ To su bili pesma Alekse Šantića „Ostajte ovde“, pesma Dušana Simića „Bosna“, kao i odlomci iz pri-

${ }^{10}$ Bapgap, каленgap за pegoвну їоguну 1907, година друга, издање Друштва „Кола српских сестара“, Београд, (1906), штампано у Државној штампарији Краљевине Србије, 1906. (стр. 84+3); формат 25 x 16,5 cm; тираж 30.000 примерака. 
povetke Petra Kočića „Tri zemana iz starostavne knjige Simeuna đaka“. Objavljene su i fotografije Sarajeva i Mostara sa prigodnim, opširnim tekstom. Interesantan je tekst kojim je propraćena fotografija Sarajeva: „Tek u poslednje vreme Sarajevo počinje da se otima i budi, da se otresa čamotinje u koju ga je uvila okupacija. Ima desetak godina kako je otpočeo snažan pokret među muslimanima i pravoslavnima: uvideli su se zajednički interesi i potreba za zajedničkim radom. ... Te pojave su glasnici novoga doba, koje mora nastupiti u okupiranim zemljama i koje će dati narodu ono što svi narodi u Evropi uživaju: slobodu." U ovom broju štampane su i dve patriotske pesme, St. Vladislava Kaćanskog „Narodni Zbor“ i Dragutina J. Ilića „Srbinu“, u kojima se pominju svi Srbi koji žive van Kraljevine, uz poziv na ujedinjenje radi oslobođenja.

Političke prilike na Balkanskom poluostrvu i nacionalni interesi Kraljevine Srbije diktirali su i teme koje su se obrađivale u Vardaru. U trećem broju kalendara opet je veliki broj priloga posvećen Staroj Srbiji i Makedoniji. ${ }^{11}$ Međutim, već na početku je štampan tekst Petra Kočića „Molitva“, napisan stilom molitve: „Znam ja to sve i osjećam, ali mi ne daju pjevati o srećnim danima minula vremena, ali mi ne daju kukati nad opštim jadom tvojim, Narode moj zarobljeni, i kukavna Otadžbino moja!“ Objavljena je i pesma Alekse Šantića "O zemljo moja..." i fotografije Banja Luke i Nevesinja sa propratnim tekstovima. U tekstu se kaže da je posle Sarajeva Banja Luka najveći i najvažniji grad u Bosni, koji je politički najznačajnija tačka za srpstvo ovih krajeva: „Danas je ona srpska straža na Krajini ljutoj, rasadnik ideja za veliku zajednicu Srpstva.“ U ovom broju je štampana i „Karta srpskih i ostalih jugoslovenskih zemalja“, kao prilog uz opširan tekst o njoj. Kolo je tako nastavilo dobru tradiciju drugih patriotskih društava koja su u svojim glasilima ili kao samostalna izdanja objavljivali karte srpskih ili jugoslovenskih zemalja. Po preporuci Jovana Cvijića Kolo je angažovalo Svetozara Tomića da uradi ovu kartu uz koju je objavio i opširan tekst o tome kako je karta nastala i zašto je obuhvatio sve jugoslovenske zemlje. Od priloga opšteg karaktera štampan je tekst „Kako se Srbi mogu privredno oporaviti“ namenjen i Srbima van granica Kraljevine, sa praktičnim privrednim i ekonomskim savetima. Bilo da je reč o prilozima političke, ekonomske ili kulturne orijentacije, svaki je tekst korišćen da se skrene pažnja na zadatke koji stoje pred tom generacijom Srba. Tekst pod nazivom „Vek vaskrsa Srbije i njen napredak u 19. veku“", koji govori o stvaranju srpske države od ustanaka do savremenih dana, završava se rečima: „Ne samo na savremenom naraštaju stoji dužnost, da mučno stečene tekovine svojih starih

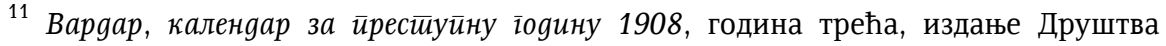
„Кола српских сестара“, Београд, (1907), „Доситеј Обрадовић“, штампарија Аце М. Станојевића, тираж 20.000 примерака (стр. 97+8), формат 24 х $16 \mathrm{~cm}$. 
očuva, već da sebe, zemlju i narod svoj, i novim tekovinama obogati. U tome je naš opšti napredak; $u$ tome je naše narodno spasenje i naša budućnost - budućnost, ne samo Srbije, no i celog nedeljivog Srpskog Naroda, koji ... nezaboravimo to!... traje mučne dane u teškoj borbi za opstanak...".

Vardar za 1909. godinu, koji je štampan krajem 1908, donosi odjeke i reakcije na aneksiju Bosne i Hercegovine kao najvažnijeg događaja za srpski narod. ${ }^{12} \mathrm{U}$ tom duhu je pisan i veći deo Izveštaja društva u kome se govori o odlasku članica Kola u Bosnu i kontaktima koje su uspele da ostvare sa tamošnjim svetom. Članice društva su prikupljale sredstva za školovanje srpskih devojaka iz Bosne, a širile su i krug ličnih veza, pa su tako kumovale osvećenju zastave pevačkog društva „Milutinović“: „One opet vratile su se odande do dna duše potresene bratskim gostoljubljem, kojim su bile dočekane i silnim osećajima svesnog rodoljublja na koje su naišle." Kao prva ilustracija u kalendaru se izdvaja kompozicija sačinjena od devet portreta hercegovačkih vojvoda i opširnog teksta koji je posvećen njima i ustanku iz 1875. godine. Pored ove kompozicije u kalendaru je objavljen i tekst Radovana Perovića Nevesinjskog „Krv nije voda“ u kome se iznose istiniti događaji iz prvog i drugog hercegovačkog ustanka. Ove teme su bile namenski obrađene i svojim primerima su uzdizali svest srpskog naroda, ukazivali na mogući put i rešenje teškog položaja. U istom tonu su govorili i stihovi Stevana Bard - Kaćanskog i njegove pesme „Jadna Bosna“. Iz sadržaja ovog broja kalendara izdvajaju se dva teksta, rad Stanoja Stanojevića "Položaj Srpskog naroda" koji je bio jedna vrsta rezimea njegovog dela Istorija srpskog naroda. U kratkoj sintezi na svega sedam strana prikazao je položaj srpskog naroda kroz istoriju i trenutno stanje u kome je on razapet između velikih sila. Tekst Živojina M. Protića, jednog od urednika Dnevnika i redovnog autora $\mathrm{u}$ kalendaru, „Ujedinjenje srpskog naroda (misli i opažanja posle aneksije Bosne i Hercegovine)“ posvećen je stanju u kome se nalazio srpski narod posle aneksije: „Za naš narod aneksija pak znači drugo nešto. Ona nas, na ime, postavlja pred novu borbu, mnogo težu i opasniju od dosadašnje, odgađa novu borbu, odgađa za neizvesna vremena zadovoljenje naših nacionalnih zahteva, za koje smo mi do sada podneli tolike krvave žrtve." Iako zaključuje da je novo stanje u Bosni i Hercegovini duboko zabrinulo sve tamošnje srpske radnike, smatra da će se naći snaga i mogućnosti i suprotstaviti takvoj politici Austro-Ugarske. Analizirajući situaciju u Italiji pred ujedinjenje, autor u stvari govori o mogućnostima, pa čak i oružanim akcijama koje će Bosnu ujediniti sa Srbijom i Crnom Gorom: „Ništa nije još izgubljeno. Počinje jedna nova borba, za koju smo već izme-

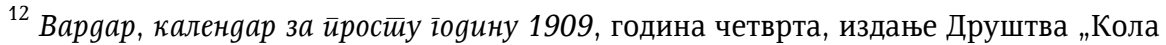
српских сестара“, Београд, (1908), Нова штампарија „Давидовић“ Љуб. М. Давидовића, тираж 22.000 примерака (стр. 144+8), формат 24 х $16 \mathrm{~cm}$. 
rili svoju snagu. Za tu borbu treba se naoružati najiskrenijim rodoljubljem, slobodnim srcem i junačkom mišicom." Od ilustracija su objavljene još fotografije Gligorija Jeftanovića i Vojislava Šole, predvodnika pokreta srpskog naroda u Bosni i Hercegovini koji se borio za crkveno-školsku autonomiju, a iz kog je kasnije proizišao i politički pokret. Osim toga objavljena je fotografija Stoca i vodopada u Jajcu.

Kalendar Vardar je svojom sadržinom počeo vrlo brzo da smeta austrougarskim vlastima. U Bosni i Hercegovini, kao i na čitavoj teritoriji Austro-Ugarske bila je zabranjena prodaja kalendara. Nekoliko brojeva koji su poslati knjižaru u Pančevo policija je zaplenila i spalila. „No time je postigla to, da je Vardar postao još omiljenija srpska knjiga...: za tu ljubav nema zabrane“. Čak je i na Veleizdajničkom procesu u Zagrebu rad Kola srpskih sestara proglašen revolucionarnim i opasnim po interese Austro-Ugarske. U optužnici su citirani čitavi pasusi iz pojedinih članaka u kojima se propagira duhovno jedinstvo među srpskim pokrajinama, što je i poslužilo kao izgovor za zabranu prodaje kalendara.

Posle Mladoturske revolucije, donošenja novih zakona i opšte amnestije na teritoriji Osmanskog carstva došlo je do pomeranja težišta interesovanja patriotskih i nacionalnih organizacija, pa i Kola srpskih sestara, na događaje u Bosni i Hercegovini. ${ }^{13}$ To se može videti i u sadržaju Vardara za 1910. godinu, jer je odmah posle uvodne pesme, a pre izveštaja društva štampana pesma Milutina Jovanovića „Na Drinu!...“ iz zbirke „Vojničkih pesama", napisana u januaru 1909. godine. O glavnoj temi broja se govori i u Izveštaju o radu društva u prethodnoj godini: „Ali nikada Kolu Srpskih Sestara nije bilo teže odgovoriti svome teškome zadatku, nego prošle godine $;^{14}$ jer ta godina je ostavila tužan spomen u srpskoj istoriji; u njoj su Srpstvu nasilno oduzete dve najlepše njegove pokrajine, Bosna i Hercegovina. Nema srpskoga oka koje nije oplakalo ovaj gubitak, nema srpske duše koju nije potresao ovaj udar, nema srpskoga srca koje nije uzdrhtalo pravednim gnevom na tu najnoviju nepravdu nanetu srpskome plemenu." Dalje se u izveštaju navodi da je u slučaju izbijanja rata, društvo počelo da prikuplja sanitetski materijal i otvorilo je i svoje vanredne bolničke kurseve. U ovom broju su samo tekst „Srbi u ustavnoj Turskoj“, nekoliko narodnih lirskih pesama i nekoliko ilustracija posvećeni Staroj Srbiji i Makedoniji. Objavljeno je i nekoliko tekstova o događajima u drugim krajevima, poput teksta o Dubrovniku, o Veleizdajničkom procesu u Zagrebu, srpsko-hrvatskoj koali-

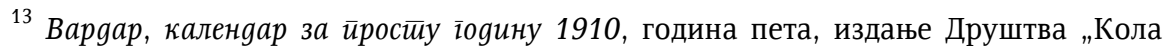
српских сестара“, Београд, (1909), Нова штампарија „Давидовић“ Љуб. М. Давидовића, тираж 20.000 примерака (стр. 152+9), формат 25 x $16 \mathrm{~cm}$.

${ }^{14}$ Misli se na 1908. godinu, jer je Izveštaj o radu društva pisan 1909. godine, kada je štampan i ovaj broj kalendara. 
ciji. Veći deo tekstova i ilustracija je ipak posvećen Bosni. Centralno mesto zauzima tekst „O Bosni i Hercegovini" potpisan samo inicijalom D., ali je verovatno reč o Dušanu Vasiljeviću, potpredsedniku Narodne organizacije Srba u Bosni i Hercegovini. Autor piše da Bosna i Hercegovina nije „ivična, nego centralna zemlja srpskog naroda". U tekstu se govori o odjecima na aneksiju Bosne i Hercegovine i novoj literaturi na tu temu. Pažnja čitalaca se usmerava na delo Jovana Cvijića i Dušana Vasiljevića, daje se kratak istorijski prikaz, a veći deo članka je posvećen životu pod vlašću AustroUgarske. Kao najveći uspeh ističe što su se u borbu za crkveno-školsku autonomiju uključili svi elementi, pa čak i oni uvek konzervativni pripadnici čaršije, bogati trgovci, preduzetnici. Doduše u tako organizovanom otporu možda treba tražiti i razloge za pojavu drugih, revolucionarnih i ekstremnijih elemenata. Oni su se deset godina borili i došli samo do prosvetne autonomije, dok se mlađe generacije sa tim nisu slagale, zahtevale su brže i drastičnije rešenje stanja. U tekstu se posebno ističe uloga društva „Prosvjeta" koje je nastalo kao potporno društvo koje je pomagalo školovanje srpske dece, ali vrlo brzo se pretvorilo u pravo prosvetno društvo. Društvo je izdržavalo preko sto srpskih škola, zanatskih društava, dobrotvornih zadruga na koje je uspevalo da prikupi preko milion i po dinara godišnje. Na kraju teksta zapisane su gotovo proročke reči: „Pošto se narod u Bosni i Hercegovini deli na tri vere, s raznim političkim ubeđenjima, srpsko pitanje u ovim zemljama ima drukčije zadatke, i mora se rešavati drukčijim metodima nego u drugim zemljama. Ovo su srpske zemlje gde se srpsko pitanje ne sme identifikovati s pitanjem pravoslavlja. Kako će se katolici i Muslimani ponašati prema Srpstvu, u opšte, zavisi koliko od njihovih odnošaja s pravoslavnim u Bosni, i od opštih odnošaja srpsko-hrvatskih, još više od toga, hoće li slobodne srpske države imati vidnih političkih uspeha, osobito teritorijalnih povećavanja."

Još jedan prilog je $u$ ovom broju zauzeo značajno mesto - bio je to tekst Živojina Protića "Na šta nas budućnost opominje“. Bio je to na neki način nastavak Protićevog teksta iz prethodnog broja kalendara, pisan sav u patriotskom i propagandnom duhu. Tekst zaključuje rečima: „U ova burna vremena, prepuna iznenađenja i tajni, ne može se ništa sa sigurnošću predvideti. Sve se menja i sve je moguće. Sigurno je samo da su na pomolu najozbiljniji istoriski događaji, koji će, možda, iz osnova promeniti današnji red stvari." Od književnih priloga vredno je pomenuti da je objavljena pesma Jelene Dimitrijević „Pobunjena duša“, patriotska pesma podrške srpskom narodu na okupiranim teritorijama. Objavljene su i dve pesme Alekse Šantića "Moja otadžbina“ i „Mi znamo sudbu“. Takođe je štampana priča redovnog saradnika Vardara Petra Kočića „Vukov Gaj“, a prvi put je pripovetku „Moj otac" u kalendaru objavio i Jovan Dučić, inače prijatelj Delfe Ivanić iz 
studentskih dana u Ženevi. Od ilustracija su objavljeni portreti dr Dušana Vasiljevića, vojvode Ivana Musića, oca Delfe Ivanić, Avde Karabegovića uz propratne tekstove. U kalendaru su se našle i fotografije ulice u Sarajevu, Konjica, Sanskog mosta, Prijedora kao i karta Bosne i Hercegovine.

Tokom 1910. godine sva pažnja je bila opet usmerena ka Staroj Srbiji i Makedoniji, pregovorima o Balkanskom savezu i putu kralja Petra u Carigrad. Te teme su i zauzele centralno mesto u Vardaru za 1911. godinu. ${ }^{15}$ Svaki tekst je bio povod da se kaže još neka reč o ujedinjenju, pa je i tekst Živojina Protića o Kavuru završen rečima: „Treba i u nas stvoriti prilike, u kojima će misao o jedinstvu postati ona velika i sveta stvar, radi koje ćemo svi mi zaboraviti na svoju ljubav, na svoja ognjišta i svoje živote." Pored teksta Radoslava M. Grujića „Srbi pod Austro-Ugarskom“, objavljen je i tekst „Bosna i Hercegovina posle aneksije“, bez potpisa. U ovom tekstu se govori o načinu organizovanja Srba, njihovoj borbi za prosvetnu i kulturnu, a potom i političku autonomiju. U očekivanju proglašenja ustava koji je car obećao u aneksionom manifestu, već u aprilu 1909. skupština najviđenijih ljudi izabrala je dva odbora koji će voditi pripreme za saborske izbore. Dalje se u tekstu govori o načinu izbora za Sabor i njegovim nadležnostima. Takođe se donosi kratak osvrt na rad novčanih zavoda, „Prosvjete“ i zidanja njihovog doma, osnivanja „Srpskog kluba“. Pored politički obojenih i patriotskih tekstova objavljena su i dva književna priloga i to pesma Stevana Beševića „Himna Balkanu“ i Alekse Šantića „Na molitvi“. Od ilustracija sa propratnim tekstovima štampane su fotografije Petra Kočića, arhimandrita Melentija, starešine manastira Duži u Hercegovini, škole i crkve u Bosanskoj Dubici, Bosanske Krupe i Trebinja, izvora Radobolje kod Mostara.

\section{Pogledi preko Drine}

Svaku priliku koja im se pružala članice Kola su koristile da održe i prodube svoje veze sa prijateljima i patriotama iz Bosne i Hercegovine. Tako je i Delfa Ivanić u septembru 1911. otputovala u Sarajevo na sahranu Adeline Pavije Irbi, velike srpske dobrotvorke. Ona je preminula 15. septembra 1911, a svoj imetak, pokretan i nepokretan od 4 miliona kruna dala je u dobrotvorne ciljeve i odredila da njime rukovode „Prosvjeta“ i Srpska ženska zadruga u Sarajevu. Delfa Ivanić je na put krenula po želji kralja Petra I Karađorđevića. Kralj je mis Irbi bio veoma zahvalan zbog pomoći koju mu je pružala tokom njegovog boravka u Bosni u redovima ustanika 1875. godine. Sa Delfom je krenuo i Živojin Dačić, sekretar Narodne

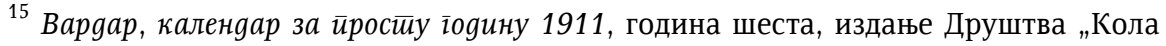
српских сестара“, Београд, (1910), Нова штампарија „Давидовић“ Љуб. М. Давидовића, тираж 20.000 примерака (стр. 148+12), формат 24 × $16 \mathrm{~cm}$. 
odbrane. Dačić je trebalo da položi venac u ime kralja Petra, srpske vlade, Akademije nauka, Narodne skupštine i Narodne odbrane, a Delfa osam venaca $u$ ime svih ženskih društava. Iako su pripremili i kratke govore, nisu ih održali jer su im austrijske vlasti zabranile. Od samog prelaska granice njih dvoje su stalno bili pod prismotrom austrijske tajne policije. U Sarajevu su zatekli Srbe podeljene u četiri tabora: jedna grupa je bila okupljena oko Jeftanovića, druga oko Petra Kočića, uz još dve zasebne grupe. Dačić je tada tajno održao predavanje u želji da se razlike prevaziđu, a Srbi ujedine. Ovaj boravak u Bosni su iskoristili da odu i do Banja Luke kako bi se sastali sa tamošnjim članovima Narodne odbrane, čiji je član bila i Delfa Ivanić, kao i mnoge druge članice Kola. Zbog mogućnosti da ih austrijske vlasti uhapse, Delfa Ivanić i Dačić su iz voza izašli pre Banja Luke, pa su sa svojim domaćinima kolima otišli do grada. Svaki svoj odlazak u Bosnu koristile su i druge članice Kola kako bi produbile svoje stare ili stvorile nove veze, poznanstva i kontakte. Još jedna od važnih karika u odnosu Srba sa jedne i druge strane Drine bio je Nikola Kašiković, osnivač i urednik Bosanske vile.

Posle povratka iz Sarajeva Delfa Ivanić je za naredni broj Vardara pripremila tekst o mis Irbi, sa svojim zapažanjima iz Sarajeva. ${ }^{16}$ U Izveštaju društva se takođe pominje i poseta pevačkog društva Sloga iz Sarajeva, koje je sa Kolom održavalo prisne veze. U ovom broju su uglavnom objavljeni književni tekstovi posvećeni Bosni i Hercegovini, što je bilo u skladu sa tadašnjom državnom politikom. Jedini tekst, politički obojen, govorio je o nastanku Narodne odbrane, potpisan inicijalima N. Pr. U njemu se govori o razlozima nastanka ovog društva koje je u vreme aneksije stvoreno kao organizacija za prikupljanje dobrovoljaca i materijalnih sredstava. Posle okončanja krize društvo se pretvorilo u kulturno-nacionalnu organizaciju sa ciljem da „koncentriše, oživi i preporodi privatnu inicijativu u Srbiji koja bi se pripremila za dalju borbu“. U Narodnoj odbrani su se okupili predstavnici svih društava, često i sukobljenih suparnika, koje je ujedinila borba za nacionalne i patriotske ciljeve. U tekstu je naročito istaknuta dobra saradnja sa „Kolom srpskih sestara“, čije su gotovo sve članice postale članice Narodne odbrane. Od književnih tekstova objavljena je pesma Alekse Šantića „Orluj klikći, orle beli...", lirska proza Petra Kočića „Kmeti“ i pripovetka Svetozara Ćorovića „Iz tamnice“. Objavljeni su uz odgovarajuće tekstove portreti vojvode Stojana Kovačevića, Svetozara Ćorovića, Alekse Šantića, Nikole T. Kašikovića, kao i fotografije Bosanskog Novog i Prijedora. Povećan broj portreta i biografija u poslednja dva broja kalendara je očigledno

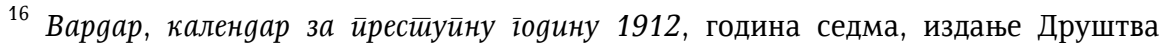
„Кола српских сестара“, Београд, (1912), Нова штампарија „Давидовић“ Љуб. М. Давидовића, тираж 20.000 примерака (стр. 146+22), формат 25 х $16 \mathrm{~cm}$. 
bila smišljena namera kako bi se srpskoj javnosti predstavili i likom i delom kulturni radnici i patriote iz Bosne i Hercegovine.

Gotovo čitav broj Vardara za 1913. godinu bio je posvećen uspešno završenom Prvom balkanskom ratu, ali obojen slutnjama u očekivanju budućeg rata. ${ }^{17}$ Opšta situacija je diktirala i uredničku koncepciju, pa su o Bosni i Hercegovini štampana samo dva teksta M. Pavlovića „Proslava desetogodišnjice Prosvjete u Sarajevu“ i tekst koji nije potpisan „Bosna i Hercegovina“. U tekstu o proslavi društva "Prosvjeta“ pominje se uspešna borba za crkveno-školsku autonomiju koja je završena ali otvara put za političku i ekonomsku borbu. O proslavi se kaže: „To nije bila samo proslava jedne kulturne ustanove; to je bila sjajna manifestacija velike srpske narodne duše, koja je izgovorila veliku reč bratstva i jednakosti; to je bila manifestacija duhovne i moralne snage srpskog naroda, koja se u ovom trenutku pokazala u svom sjaju i veličini." U tekstu o Bosni i Hercegovini govori se o istoriji ovog prostora, zajedništvu, uz često ponavljanje da su Bosna i Hercegovina srpske zemlje. Posebno se mesto daje Srbima muslimanske veroispovesti: „Mlađi naraštaj Muslimana, koje je predvodio rahmetli pesnik Osman Đikić, a sada vode Smajilaga Ćemalović i Murad Sarić oseća potpuno srodstvo i jednokrvnost sa pravoslavnom braćom; stariji Muslimani upravljaju se prema prilikama i žive tradicijama - nisu Turci, nisu Hrvati, a neće da se priznaju Srbima iz političkih razloga; te tako su kao onaj čardak iz nar. pripovetke ni na nebu ni na zemlji." Objavljena su dva književna priloga, jedan zapis iz naroda i pesma Alekse Šantića „Poklič“. Od ilustracija propraćenih tekstom tu su fotografije Luke Grđića - Bjelokosića, Sime Markovića predsednika „Prosvjete“, Pere Stokanovića, Osmana Đikića i grupe Srba muslimana iz Sarajeva, Mostarskih sokola, kao i Prosvjetnog doma u Sarajevu, Ljubinja, Bileće i Gackog, Tuzle.

Pobede srpske vojske $\mathrm{u}$ balkanskim ratovima $\mathrm{u}$ mnogome su promenile politički ugao posmatranja i u Kraljevini Srbiji, ali još više u Bosni i Hercegovini. Iako je veći deo broja Vardara za 1914. godinu bio posvećen okončanim ratovima, ima i tekstova i o srpskom narodu koji je još jače upirao pogled ka Kraljevini. ${ }^{18}$ Smail-aga Ćemalović napisao je tekst „Nacionalizam i muslimani" u kome govori o tome kako su se pravoslavni i katolički delovi „našeg naroda“ bolje snašli od muslimanskog u novom poretku pod austrijskom vlašću. Ističe pravoslavne kao uzor za organizaciju i način borbe za očuvanje nacionalnog opredeljenja. Za muslimane kaže da su se nji-

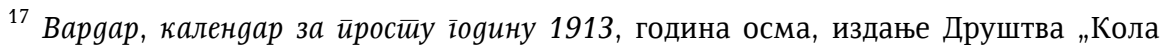
српских сестара“, Београд, (1912), Нова штампарија „Давидовић“ Љуб. М. Давидовића, тираж 20.000 примерака (стр. 165+32), формат 24 × $16 \mathrm{~cm}$.

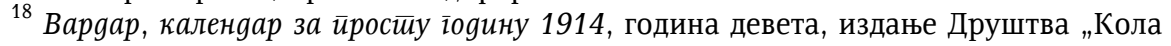
српских сестара“, Београд, (1913), Нова штампарија „Давидовић“ Љуб. М. Давидовића, тираж 20.000 примерака (стр. 165+22), формат 23 × $15 \mathrm{~cm}$. 
hovi napori ticali samo očuvanja vere i poseda, konzervativnih ciljeva koji nisu mogli da budu dobar osnov za opšti narodni napredak. „Nacionalna ideja ne samo da ne smeta u vršenju vjerskih dužnosti, nego nam je ona jedini spas, jedina podloga, na kojoj se možemo kulturno i ekonomski razvijati i tim napretkom i snagom svoju vjeru još bolje učvrstiti“, pisao je Ćemalović. Zatim govori o tome koja bi to nacionalna ideja trebalo da bude: „Istorija, naša prošlost, naš mentalitet, naša genealogija, naša kultura i naš socijalni život govore bez uvijanja i bez ikakve sumnje, da smo mi muslimani Bosne i Hercegovine Srbi i dio srpskog plemena. Mi smo sinovi srpskoga naroda ne od juče već od našega postanka. Kao Srbi primili smo Islam, kao Srbi razvijali smo se i u sredini svoje srpske braće živeli. ... Mi smo čeda jednoga naroda i jedna krv protiče kroz naše žile. ... Sve dakle govori da jednom prestanemo sa odbijanjem i prikrivanjem naše nacionalnosti i da se otvoreno izjasnimo kao nacija ili bolje dio jedne velike nacije. Da je ta nacija srpska o tome nema spora. Mi smo dakle Srbi i kao takvi stupamo u kolo naše druge braće. Vjeru svoju čuvajmo i branimo i na dalje, ali ne zaboravljajmo svoju naciju i ono, što je u današnje doba jedini uslov života i napretka."

Tekst potpisan inicijalom D. „Bosna i Hercegovina za vreme balkanskih ratova" slikovito opisuje događaje od trenutka proglašene mobilizacije u Srbiji i prvih vesti i dezinformacija koje su stizale u Sarajevo. Kada je Austro-Ugarska osporila srpske pobede u severnoj Albaniji i stvorila arbanašku državu, srpski predstavnici u Saboru i tri mitropolita uputili su protestnu izjavu u kojoj oštro osuđuju ciničnu politiku zemaljske vlade. Naravno da je to u Beču izazvalo zaprepašćenje ali i uvođenje vanrednog stanja i želju za osvetom. Austrijske vlasti su odmah udarile na srpske ustanove i zabranile su rad svim udruženjima uključujući i „Prosvjetu“. U Sarajevu, Mostaru, Foči i Banja Luci organizovani su veleizdajnički procesi. Crkve i manastiri su pretresani uz veliku štetu. Međutim, i pored progona i pritisaka, srpski narod je sa iščekivanjem gledao ka Srbiji: „Uticaji koje su ovi ratovi izvršili na srpskom narodu ostavili su u njegovoj duši nekolike trajne posledice između kojih su najvažnije ove. Stvorena je ogromna vera u snagu srpske države. Naša najbliža budućnost u svojim glavnim crtama jasna je. Ta budućnost zavisi na prvom mestu od naše uviđavnosti i našeg rada. Šta može da se za kratko vreme smišljenim radom postigne pokazala je Srbija u vremenu od 1909. do 1912. i zbog toga srpski narod u Bosni i Hercegovini veruje da će ustrajnim radom moći nadoknaditi svu onu štetu koju je pretrpeo od obesti austrijskih vlasti." Među književnim prilozima štampana je u ovom broju kalendara potresna pripovetka Svetozara Ćorovića „Skupljanje priloga". Od ilustracija i fotografija sa propratnim tekstom objavljene su fotografije Smail-age Ćemalovića, Bogdana Zimonjića, vojvode hercegovač- 
kog ustanka, Karadži-begove džamije u Mostaru, Doboja i Višegrada, Travnika, Prenj planine, vodopada Kravica, Ostrošca u Hercegovini.

\section{Vardar o Mladoj Bosni}

Tokom Prvog svetskog rata rad Kola srpskih sestara, kao i rad svih ostalih društava na teritoriji Srbije je posle okupacije zabranjen. Tako ni Vardar nije izlazio sve do 1920. godine kada se pojavio prvi broj u novoj državi Kraljevini SHS. Nova država je donela i novu uređivačku koncepciju, tekstove koji su potpisani punim imenom i prezimenom autora. Patriotski i nacionalni ciljevi proklamovani do 1914. često u prilično zavijenoj formi sada su mogli da se javno i glasno iznose. Jedini članak koji je objavljen o Mladoj Bosni jeste onaj koji je napisao Božidar Purić ${ }^{19}$ i prvi put štampao u „Dodatku“ Srpskih novina na Krfu 1917. godine. Ovaj tekst je objavljen u Vardaru za 1921. godinu. ${ }^{20}$ Purić se i sam na početku balkanskih ratova vratio sa studija prava u Parizu i kao dobrovoljac učestvovao u balkanskim, a zatim i u Prvom svetskom ratu. Po dolasku na Krf postaje pisar Ministarstva inostranih dela. Generacijski blizak pripadnicima Mlade Bosne, sa nekima se i družio u Beogradu i Parizu, dok je sa drugima zajedno ratovao kao dobrovoljac, imao je potrebu da svoje utiske o tim mladićima zapiše i podeli. Na početku teksta upoređuje Bosnu i Hercegovinu sa Šumadijom pred izbijanje ustanka i ističe razliku između čaršije i seljaka koji su bili „veliki nacionalisti i patriote, svaki na svoj način, i verovali ludo, fanatički i religiski u Srbiju“. Za razliku od njih oprezna čaršija je još uvek „imala poštovanja za ,pet miliona austriskih bajoneta'“. Između ove dve društvene grupe počela je da se pomalja i nova još radikalnija grupa - omladina, uglavnom srednjoškolska. Ta nacionalno zadojena omladina, spremna i željna akcije našla je svog novog idola i mučenika - Bogdana Žerajića. Pisac navodi i kako je, pored ostalih, i Gavrilo Princip išao svake noći na Žerajićev grob gde „urla, kuka, mrnjauče i plaši svet“. Zbog tih manifestacija omladine policija je tri puta tajno premeštala mrtvog Žerajića. „Tako je poniklo društvo „,Mlada Bosna'. ... Oni nisu imali doktrine, utvrđenog programa i statuta: nosili su ih u sebi. Njih nije stvorila i ujedinila jedna ideja a priori, već njihovo živo i atavističko osećanje za slobodu, za samopregorenje i nagon ka velikom. Prvo su radili i organizovali se, pronalazili poverljive ljude gradeći tajne kanale u celoj zemlji, hvatali vezu sa Srbijom, tražili oružja.

${ }^{19}$ Božidar Purić (1891-1977), političar, diplomata, predsednik vlade, ministar inostranih dela. Prava studirao u Parizu, gde je i doktorirao 1918. Bio je konzul u San Francisku i Čikagu, poslanik i opunomoćeni ministar u Parizu. Od 1943. do 1944. bio je predsednik vlade i ministar inostranih dela Kraljevine Jugoslavije u Londonu.

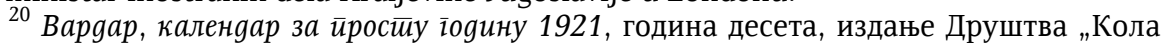
српских сестара“, Београд, (1920), Штампарија „Типографија д. д.“, тираж 35.000 примерака (стр. 128+24), формат $22 \times 14,5 \mathrm{~cm}$. 
Teorija, formula i fraza bili su sporedni i bez važnosti. Primala se sva sredstva, svi načini do najrevolucionarnijih i najterorističkijih. Buniti se i boriti, pa ma kakvim povodom", zapisao je Purić dajući jednu od najtačnijih ocena Mlade Bosne. Kao jednog od osnivača pisac pominje Dragoljuba Kesića, poznatog iz agrarne pobune 1910. godine, kada su ga vlasti uhvatile i obesile. Jedan od učesnika pokreta bio je i Jovan Živković, koji je putovao u Francusku i Švajcarsku, sa namerom da radi organizacije ide i u Ameriku. Ovu grupu mladih ljudi opisuje sledećim rečima: „Imali su nečeg neobičnog i naročitog na sebi, odblesak unutrašnjeg nadahnuća, jedne duševne uznemirenosti, borbe i velikih rešavanja. Goreli velikom srčanom vatrom, preživljavali krizu volje, bili u groznici nesvesnog i stvaralačkog. Nešto se veliko dešavalo u njima, s njima i oko njih. Imali su predosećanje nečeg nepoznatog i dramskog, čuvstvovanje unapred bogom i sudbinom određene uloge i pisanog kraja." Najveći problem je po autoru bilo nepostojanje ideologije, doktrine, što je i bio glavni razlog za tako nestrpljivu želju da se što pre krene $u$ akciju. Kao ostale pripadnike Mlade Bosne, pored neposrednih učesnika u atentatu, navodi i Danila Ilića, učitelja obešenog u Sarajevu, dok je Jovan Živanović uhvaćen kao dobrovoljac u Višegradu i živ spaljen na sred varoškog trga. Navodi i druge članove Mlade Bosne: Omer Sefo, poginuo na Zakuti kao dobrovoljac, Petar Petković Ćelo student tehnike, urednik mostarskog Rada, Kočićev najodaniji pomoćnik, učesnik balkanskih ratova, poginuo na Zavlaci, Nikola Počuča, gimnazijalac, dobrovoljac od 1913. poginuo na Dobrom Polju, Borivoje Jeftić književnik, umro u tamnici posle atentata, Miloš Vidaković pesnik, kao dobrovoljac umro 1915. u Velesu od tuberkuloze, Slovenac Dragutin Mraz pesnik i revolucionar, poginuo 1915. kod Požarevca. Poseban, gotovo lirski deo teksta Purić je posvetio pobratimima, Mostarcima Risti Milićeviću i Risti Toholju, studentima i dobrovoljcima balkanskih ratova. Milićević je jedno vreme u Beogradu stanovao u istoj sobi sa Principom. Poginuo je 1914. kod Krupnja. Toholj je poginuo na čelu 2. dobrovoljačkog puka u borbama sa Bugarima. Tekst zaključuje rečima: „Mlada Bosna ispunila je svu svoju dužnost. Ona je jedan visoki moral i jedan svetao primer. Bili su veliki, jer su imali jedno veliko osećanje, i otišli su u besmrtnost pretvarajući ga u akciju. Kod njih su reči bile dela, i fraza, koja bi ostala nepotvrđena pokretom, smatrala se za izdajstvo. Oni su skoro svi izginuli, i što ih je ostalo, to je bolesno i izmučeno ratovima i tamnicama. Oni su naša velika etička lepota i nacionalna svetlost, po kojoj će se pokoljenja upravljati. Oni su čestitost i pošteni obraz svoje zemlje."

To je bio jedini tekst posvećen članovima Mlade Bosne koji je Vardar doneo, uz fotografiju Gavrila Principa objavljenu u kalendaru za 1925. godinu ali bez propratnog teksta. 
Tabelarni prikaz priloga o Bosni i Hercegovini objavljenih u Vardaru 1906-1921.

\begin{tabular}{|l|r|r|r|r|r|r|r|r|r|r|r|}
\hline & 1906 & 1907 & 1908 & 1909 & 1910 & 1911 & 1912 & 1913 & 1914 & 1921 & Ukupno \\
\hline $\begin{array}{l}\text { Tekstovi } \\
\text { opšteg i poli- } \\
\text { tičkog tipa }\end{array}$ & - & - & 1 & 3 & 2 & 2 & 2 & 2 & 2 & 1 & 15 \\
\hline $\begin{array}{l}\text { Tekstovi o } \\
\text { ekonomskim } \\
\text { temama }\end{array}$ & - & - & 1 & 1 & - & - & & & & & 2 \\
\hline Pesme & - & $3+2$ & 1 & 1 & 4 & 2 & 1 & 1 & 1 & 1 & 17 \\
\hline $\begin{array}{l}\text { Prozni } \\
\text { tekstovi }\end{array}$ & - & 1 & - & - & 2 & - & 2 & 1 & 2 & 2 & 10 \\
\hline $\begin{array}{l}\text { Ilustracije } \\
\text { sa propratnim } \\
\text { tekstom }\end{array}$ & - & & & & & & & & & & \\
\hline Karte & - & - & 1 & - & 7 & 6 & 6 & 12 & 9 & & 48 \\
\hline Ukupno & & 8 & 6 & 10 & 16 & 10 & 11 & 16 & 14 & 4 & 94 \\
\hline
\end{tabular}

\section{Zaključak}

Kalendar Vardar je odigrao važnu patriotsku i propagandnu ulogu u stvaranju i buđenju nacionalne svesti srpskog naroda na teritorijama pod tuđinskom vlašću. Kao glasilo jednog humanitarnog društva bio je sredstvo koje je moglo da proširi glas lakše i brže nego cenzurisana i zabranjivana zvanična glasila Kraljevine Srbije. To je uredništvo znalo i vešto koristilo na više načina. U devet brojeva štampanih od 1906. do 1920. ukupno su objavljena 94 različita priloga o Bosni i Hercegovini. Od tekstualnih priloga najviše je bilo tekstova sa političkim i opštim temama i patriotskih i rodoljubivih pesama. Ubedljivo je najviše bilo likovnih priloga - ilustracija, fotografija, crteža. Objavljeno je ukupno 48 likovnih priloga koji su propraćeni odgovarajućim tekstovima. Posebno je interesantno da su ti tekstovi objavljivani na kraju kalendara, sitnijim slogom i da su često govorili i više nego što bi se moglo reći u običnom tekstu.

Primaran cilj osnivača i uredništva Vardara bio je dvojak, s jedne strane stanovništvo Kraljevine Srbije je trebalo upoznati sa teškim položajem Srba van granica zemlje, teritorijama i gradovima u kojima oni žive, znamenitim manastirima i crkvama na tim teritorijama. Kako kalendar nije bio zvanično glasilo, nije morao da vodi mnogo računa o tonu tekstova. S druge strane, patriotske i nacionalne ideje je trebalo plasirati van granica Kraljevine, upoznati i obrazovati tamošnje Srbe sa težnjama matice, uliti im nadu o skoroj slobodi i ujedinjenju. Zato je Vardar odigrao značajnu propagandnu aktivnost i u Staroj Srbiji, ali i u Bosni i Hercegovini kao i u drugim krajevima nastanjenim Srbima. 


\section{IZVORI I LITERATURA}

- Варgар, каленgар Друшишва „Коло срӣских сесиара“ (Београд, 19061920).

- Иванић, Делфа И. „Пре двадесет година“. Bapgap, каленgар за 1924. Београд, (1923), 2-32.

- Иванић Delfa. Усйомене. Приредила Јасмина Милановић. Београд: Институт за савремену историју, 2012.

- Милојевић-Шуловић Љиљана, и Будимир Павловић, Коло срйских сестиара и Краљииа Марија. Београд: Љ. Милојевић-Шуловић, Б. Павловић, 2000.

- Симијановић, Јован. „Календар Вардар о Старој Србији“. Башишина, св. 24, Приштина-Лепосавић, (2008), 191-200.

Jasmina Milanović

\section{BOSNIA AND HERCEGOVINA IN VARDAR - CALENDAR OF THE KOLO SRPSKIH SESTARA SOCIETY}

\section{Summary}

Humanitarian society of Kolo Srpskih Sestara, founded in Belgrade in 1903, directed its main goal towards helping the Serbian people living in the Ottoman and Austro-Hungarian Empire. In 1906, the society started printing its annual calendar, simbolically named Vardar. Its content was adjusted to their main mission, as well as the literary works and illustrations which were published. In 1908, with the position of Serbian people changing in Old Serbia and Macedonia, the emphasis was moved to Bosnia and Herzegovina. The positions of Serbs in these territories became the main subject of the calendar. Many letters were sent to the editorial office from Sarajevo, Banja Luka and other places. Every opportunity was used for a closer contact and exchange of information. This is why the members of the society of Kolo Srpskih Sestara sent their managing member and founder Delfa Ivanić to the funeral of famous Adelina Irbi in Sarajevo in 1911. She travelled along with Živojin Dačić, secretary of organization Narodna odbrana (National Defense), so they used their visit to Sarajevo and Banja Luka for other activities, naturally under the watchful eye of the Austro-Hungarian authorities. The editorial staff of Vardar kept tight connections with Nikola Kašiković, editor of Bosanska Vila, as well as with the 
members of the Humanitarian Collectives of Serbian Women in Sarajevo and Banja Luka.

KEYWORDS: Bosnia and Herzegovina, Kolo Srpskih Sestara, calendar Vardar, Narodna odbrana, Nikola Kašiković

\section{LA BOSNIE-HERZÉGOVINE DANS LE VARDAR - CALENDRIER DE LA KOLO SRPSKIH SESTARA}

\section{Résumé}

L'association humanitaire Kolo srpskih sestara, fondé à Belgrade 1903. A proclamé pour le but principal l'aide aux peuples serbes sous l'Empire Ottomane et l'Empire austro-hongrois. Depuis l'année 1906, l'association a commencé à publier le calendrier annuaire, symboliquement nommé Vardar. Le contenu du calendrier a été approprie au but principal, ainsi que les textes littéraires et illustrations publiées. Depuis l'année 1908. et le changement de la position du peuple serbe dans l'ancienne Serbie et la Macédoine, on a mis l'accent sur la Bosnie-Herzégovine. La position des Serbes sur ces territoires est devenue le sujet principal du calendrier. La rédaction recevait de nombreuses correspondances de Sarajevo, Banja Luka et autres endroits. On a profité de toute occasion possible pour établir un contact plus étroit et échanger les informations. Comme ça, Kolo srpskih sestara a envoyé son membre dirigeant et fondatrice Delfa Ivanić, à l'enterrement de la célèbre Adelina Irbi, à Sarajevo, 1911. Elle a voyagé avec Živojin Dačić, secrétaire de la Narodna odbrana (Défense civile), donc, ils ont profité de leur sejour et leur visite à Sarajevo, pour d'autres activités, bien sûr toujours surveillés par les autorités austro-hongroises. La rédaction du Vardar gardait de liens étroits avec Nikola Kašiković, rédacteur de Bosanska Vila, et avec les membres des fondations de bienfaisance des Femmes serbes à Sarajevo et à Banja Luka.

MOTS CLÉS : Bosnie-Herzégovine, Kolo srpskih sestara, le calendrier Vardar, Narodna odbrana, Nikola Kašiković 